University of Nebraska - Lincoln

DigitalCommons@University of Nebraska - Lincoln

March 1998

\title{
From Compassion to Compensation: The Effect of Injury Severity on Mock Jurors' Liability Judgments
}

Brian H. Bornstein

University of Nebraska-Lincoln, bbornstein2@unl.edu

Follow this and additional works at: https://digitalcommons.unl.edu/psychfacpub

Part of the Psychiatry and Psychology Commons

Bornstein, Brian H., "From Compassion to Compensation: The Effect of Injury Severity on Mock Jurors' Liability Judgments" (1998). Faculty Publications, Department of Psychology. 210.

https://digitalcommons.unl.edu/psychfacpub/210

This Article is brought to you for free and open access by the Psychology, Department of at DigitalCommons@University of Nebraska - Lincoln. It has been accepted for inclusion in Faculty Publications, Department of Psychology by an authorized administrator of DigitalCommons@University of Nebraska - Lincoln. 


\title{
From Compassion to Compensation: The Effect of Injury Severity on Mock Jurors' Liability Judgments ${ }^{1}$
}

\author{
Brian H. Bornstein ${ }^{2}$ \\ Louisiana State University
}

\begin{abstract}
Two studies were performed to ascertain the effect of injury severity on participants' judgments in a simulated jury task. Participants read a summary of a personal-injury case in which the severity of the plaintiff's injury was varied: they were asked to judge the defendant's liability, award compensation, and rate their feelings toward the litigants. In Study 1, more severely hurt plaintiffs were more likely to obtain a favorable verdict, even though evidence of liability was held constant. Greater severity influenced liability judgments only insofar as it elicited positive feelings toward the plaintiff or negative feelings toward the defendant. In Study 2, severity was found to have no effect when participants could not award damages, suggesting that more severe injuries arouse feelings for the litigants that are associated with a motivation to alleviate the plaintiffs suffering or to punish the defendant. Strategies for reducing the extralegal influence of injury severity are discussed.
\end{abstract}

Personal-injury lawsuits vary in innumerable ways, such as the number and type of defendants, the alleged cause of the injury, the number of plaintiffs, and the rule that is used in determining liability. Any or all of these factors may influence a case's outcome should it go to trial. For example, plaintiffs obtain more favorable verdicts when they sue corporate, as opposed to individual, defendants (Bornstein, 1994; Chin \& Peterson, 1985; Hans \& Ermann, $1989) ;{ }^{3}$ when the alleged cause of the plaintiff's injury corresponds well to jurors' naive intuitions regarding the origin of certain types of injury (Bornstein \& Rajki, 1994 ); as the number of plaintiffs involved increases (Horow-

${ }^{1}$ A portion of this paper was presented at the 1993 Southwestern Cognition Conference in Arlington, Texas. I am grateful to T. Carter and S. Lamoureux for running subjects, to T. Buckley for statistical advice, and to J. Wilson for helpful comments on the manuscript.

${ }^{2}$ Correspondence concerning this article should be addressed to Brian H. Bornstein, Department of Psychology, 236 Audubon Hall, Louisiana State University, Baton Rouge, LA 70803.

${ }^{3}$ In discussing this "deep-pocket" effect, it is necessary to define what constitutes a "favorable verdict." Wealthy, corporate defendants might be more likely to be found liable. without actually having to pay greater compensation once liability has been established (Bornstein, 1994; Vidmar, 1993). 
itz \& Bordens, 1988); and when a strict liability rule, rather than one requiring a demonstration of negligence, is employed (Calfee \& Winston, 1988; Landes \& Posner, 1987).

A necessary feature of all personal-injury cases is that someone has, at least allegedly, been injured. Thus, another variable in the constellation of factors that may vary across these cases is the extent of the plaintiff's injury. The same act-for instance, running a red light and hitting another carcan be identical in every detail (the cars' speed and point of impact, the drivers' mental state and use of seatbelts, the number of persons involved) except for the act's consequences. The occupant of the car that is hit, subsequently the plaintiff, might suffer injuries ranging from superficial cuts and bruises to paralysis or death.

Injury severity is of special interest in the trial context because it is often relevant to some judgments that jurors are asked to make, but not others. Specifically, it may be relevant to the awarding of compensatory damages - a plaintiff who has been hurt worse requires more in the way of restitution-but not to determining the defendant's liability for the act itself. Factual matters under dispute, such as the color of the traffic light and whether the plaintiffs car was sticking out too far into the intersection, are independent of what happened to the plaintiff after the car was hit. An effect of injury severity on liability judgments would show that jurors can be influenced by "extralegal" factors, as opposed to legally relevant evidence used in determining facts-in-issue. ${ }^{4}$

An abundance of research suggests that jurors are influenced by extralegal considerations that are present, but not formally presented, at trial (e.g.. Dane \& Wrightsman, 1982; Davis, 1989; Reskin \& Visher, 1986). For example, Kalven and Zeisel (1966) found that the majority of disagreements between judge and jury were due not to evidentiary factors, but to disagreements concerning "values" or sentiments. Specifically, judges believed that extralegal sentiments, such as feelings about an individual defendant, influenced jurors' interpretation of the evidence. Defendant characteristics mentioned by judges as capable of producing positive sentiments included age, gender, attractiveness, and occupation. The importance of these factors has been corroborated in simulation studies showing, for example, that more lenient treatment is given to female (Cruse \& Leigh, 1987) and relatively attractive defendants (Sigall \& Ostrove, 1975).

${ }^{4}$ Injury severity is also largely irrelevant to the determination of punitive damages, which are. designed to punish the defendant, rather than to compensate the plaintiff. The extent to which mock jurors are able to adhere to the purposes served by the different types of damages is unclear (Baron. \& Ritov, 1993; Cather, Greene, \& Durham, 1996). It is beyond the scope of this paper to compare the rationales behind different types of damages. It is clear, in any case, that the extent of the plaintiff's injury is more directly relevant to compensatory than to punitive damages. 


\section{Injury Severity and Liability Judgments}

Research focusing on subjects' attributions of responsibility for different types of actions has addressed the issue of an action's consequences (Burger, 1981). For example, Walster (1966) and Phares and Wilson (1972) have shown that greater responsibility for an accident is attributed to the actor as the accident's consequences become more severe.

Based on these findings, one might predict that a personal-injury defendant is more likely to be found liable (i.e., legally responsible) as the consequences for the plaintiff become more severe. However, the applicability of these findings to personal-injury trials is limited. Although the accident situations described in the attribution literature (e.g., Walster, 1966) are similar to those one might find in a personal-injury trial, they are typically not presented within a simulated trial context. Participants make responsibility attributions by assigning numerical ratings, but they are not instructed on how those ratings might correspond to a definition of legal liability and be used in reaching a verdict. The general sense of responsibility and its legal usage are clearly related (e.g., Fincham \& Jaspars, 1980), but they are not the same (Hart \& Honore, 1985). Thus, it is difficult to extrapolate from findings on the general phenomenon of responsibility attribution to a trial situation involving very specific criteria for jurors' liability judgments.

It is reasonable to assume that jurors would respond emotionally to a plaintiff who has suffered some injury, in the same way that people generally respond emotionally to the distress of others (Batson, Fultz, \& Schoenrade, 1987). According to Batson et al. (1987), this emotional response to another's suffering leads to helping behavior. Within the context of a personal-injury trial, helping the plaintiff takes the form of awarding compensation in restitution for the plaintiffs injuries, regardless of the helper's underlying motivation (i.e., the trial situation does not enable a distinction between different types of helping, as defined by Batson, O'Quin, Fultz, Vanderplas, \& Isen, 1983). Positive sentiments for an injured plaintiff could therefore contain a motivation to help by relieving the plaintiffs suffering.

Different emotions tend to be associated with different motives (Leeper, 1963; Weiner\& Graham, 1989) or states of action readiness (Frijda, 1987; Frijda, Kuipers, \& ter Schure, 1989). According to Frijda et al. (1989), action readiness is an important component of emotional experience because it is what links experience and behavior. For example, the emotion of fear is characterized by avoidance of some stimulus, while happiness motivates one to stay near a stimulus (Frijda, 1987). A more severely injured plaintiff would produce a stronger emotional response. Because emotional intensity is associated with certain cognitive appraisal patterns (Clore, 1994) and be- 
cause appraisal and action readiness are highly correlated (Frijda, 1987; Frijda, et al., 1989), a stronger emotional response would therefore be associated with a stronger action tendency to help the plaintiff by awarding compensation. Within the constraints of a formal trial, that behavior can only be accomplished given a prior judgment of liability; so injury severity would influence jurors' evaluation of the facts (an extralegal influence) in order to justify the desired outcome of compensation.

In civil cases (specifically, torts), the defendant's loss is the plaintiffs gain. Sentiment toward the litigants in personal-injury cases is reciprocal, such that increasing the positive feelings toward one party has a negative effect on jurors, feelings toward that party's antagonist (Bornstein, 1994). Thus, in addition to motivating jurors to help the plaintiff through compensation, positive sentiment for an injured plaintiff could also be associated with a motivation to punish the allegedly responsible defendant by making him pay more in damages. Both motives can only be satisfied by finding for the plaintiff and against the defendant.

\section{Experimental Overview}

The present studies address the influence of injury severity on subjects' judgments in a simulated personal-injury trial. A civil trial is used because, unlike criminal trials, the victim's suffering can be alleviated in a material way by jurors' verdict. The cases are simplified so that the sole fact-in-issue is causationthat is, whether the defendant's action is capable of causing the plaintiffs injury. Participants' task is to estimate the probability of causation, and from their causation judgments to make decisions about liability and damages. Where causation is the only fact-in-issue, an attribution of liability is a simple reflection of the causal attribution: If the defendant is more likely than not to have caused the injury (i.e., using the preponderance of the evidence standard), then he is liable; if not, then he is not liable. Although attributions of causality and responsibility are partially independent (Fincham \& Jaspars, 1980), the primary (and sometimes sole) factor in determining liability for personal injury is usually whether or not the defendant caused the plaintiffs injury (Hart \& Honore, 1985).

The purpose of Study 1 is to test whether injury severity has an effect on participants' factual judgments in the context of a personal-injury trial. Injury severity has been shown to influence attributions of responsibility, with greater responsibility being attributed for an action as the severity of its outcome increases (e.g., Walster, 1966). Injury severity is predicted to have a similar effect on jurors' judgments, where responsibility is construed as legal liability. Although severity is directly relevant to the issue of compensation, an effect on the prior determination of liability would constitute an extralegal bias.

Study 2 investigates the circumstances under which severity affects liability judgments. By varying whether or not subjects are able to award damages, 
as well as the type of damages, the role of severity in arousing an emotional response having specific action tendencies can be assessed.

\section{Study 1}

The purpose of Study 1 is to investigate to what extent the severity of the plaintiffs injury affects judgments of liability and compensation. The hypothesis is that a more severely injured plaintiff will obtain more favorable judgments than will a less severely injured plaintiff. Thus, participants' liability judgments are predicted to vary with severity, even though the evidence about the injury's cause is held constant-clearly violating legal guidelines. Sentiment for the plaintiff is predicted to be a mediating factor, such that severity in and of itself only affects liability judgments to the extent that it influences participants' feelings toward the plaintiff.

Participants' monetary awards are also predicted to vary with severity, but such an effect would not violate legal guidelines. Once liability has been established, more severely injured plaintiffs are usually entitled to greater compensation. The primary, immediate function of compensatory damages is to provide restitution; since more severely injured persons will, on average, have lost more, they will require more to achieve restitution (Landes \& Posner, 1987).

\section{Method}

\section{Participants}

The participants were 83 students who either were paid $\$ 6 / \mathrm{hr}$ for volunteering or received extra course credit. The sample consisted largely of college undergraduates between the ages of 18 and 25, although a minority of the paid volunteers were graduate students or nonstudents who responded to advertisements posted on campus (precise figures are unavailable, as this information was not requested of the participants). ${ }^{5}$

\section{Materials and Design}

A trial scenario was constructed which described a woman with ovarian cancer, who was suing a large drug company, alleging that the birth-control

${ }^{5}$ Including the form of participants' payment (money or course credit) as a factor in the analyses yielded no significant main effects or interactions. The implications of the relatively homogeneous sample for generalizing to the behavior of real jurors are considered in the General Discussion. 
Table 1

Case Summary

Trial element Description

\begin{tabular}{cl}
\hline Plaintiff & $\begin{array}{l}\text { Kathy Johnson, age 32, who has ovarian cancer. She is asking } \\
\text { for } \$ 500,000 \text { to compensate for medical costs, pain and suffer- } \\
\text { ing. }\end{array}$ \\
$\begin{array}{l}\text { Low-severity } \\
\text { injury condition }\end{array}$ & $\begin{array}{l}\text { Cancer detected early; one ovary removed, so still able } \\
\text { to have children. Excellent prognosis, with minimal chance of } \\
\text { recurrence. }\end{array}$ \\
$\begin{array}{l}\text { High-severity } \\
\text { injury condition }\end{array}$ & $\begin{array}{l}\text { Cancer detected late; both ovaries removed, so unable } \\
\text { to have children. Poor prognosis, with spread of cancer and } \\
\text { short life expectancy. }\end{array}$ \\
Defendant & $\begin{array}{l}\text { Manufacturer of birth-control pills, a large drug company. } \\
\text { Facts-in-issue }\end{array}$ \\
Evidence & $\begin{array}{l}\text { Major issue at trial is whether or not the pills cause cancer. } \\
\text { Plaintiff and defendant each call an expert witness, who pres- } \\
\text { ents results of scientific studies suggesting that defendant's } \\
\text { pills either do (plaintiffs expert) or do not (defendant's expert) } \\
\text { increase risk of ovarian cancer. }\end{array}$
\end{tabular}

pills made by the company caused her disease (Bornstein \& Rajki, 1994). The case was modified from actual lawsuits (Huber, 1988) and is summarized in Table 1. The case was one single-spaced page long and contained the following elements: (a) a description of the plaintiff, the plaintiffs injury and its consequences; (b) a description of the defendant; (c) the plaintiffs claim, requested compensation ( $\$ 500,000$ for medical costs, pain and suffering), and known facts; (d) the major issue at trial, portrayed as being whether the defendant's product is, in general, capable of causing an injury such as that suffered by the plaintiff; and (e) expert scientific testimony on both sides, constructed to be roughly equal in strength. The scientific evidence was presented in order to resolve the primary fact-in-issue of whether the pills cause ovarian cancer.

The case had both a high-severity and a low-severity injury condition (Table 1). Only the severity of the injury and its consequences differed between conditions; the nature of the injury and all other details were constant for the two versions of the case. 


\section{Procedure}

Participants were randomly assigned to either the high-severity or low-severity condition. The written instructions (taken from Devitt, Blackmar, Wolff, \& O'Malley, 1992) informed participants that the study's purpose was to address how people make decisions about legal liability. Important terms, such as "liable," "plaintiff," and "defendant," were defined, and participants were told that any money they awarded was only to compensate the plaintiff for her injury. Additionally, they were instructed that

whether or not the plaintiff has suffered actual harm is not at issuethat is given. What is at issue, and what determines liability, is whether...the defendant caused the harm. Legally, the plaintiff is not entitled to receive any monetary damages for the injury unless it is more likely than not that the defendant caused the injury

(i.e., the preponderance of the evidence standard).

Participants completed the questionnaire individually, though up to five participants were included in a single session. The questionnaire took roughly 30 to $45 \mathrm{~min}$ to complete.

\section{Dependent Variables}

Participants answered five questions concerning the case:

1. Verdict. Should the defendant be found liable (answer Yes or No)?

2. Causation estimate. On a scale from 0 to 100 , "How likely is it that the defendant caused the plaintiff's injury?" A preponderance of the evidence was defined as any score above 50 . The causation scale focused attention on the major fact-in-issue and allowed participants to make finer assessments of the evidence than a dichotomous verdict.

3. Compensation. Participants were reminded that they could not award money to the plaintiff unless they first found the defendant liable, and that they should award whatever amount they felt the case warranted. They were told further that they could find the defendant liable yet not award any money.

4 and 5. Sympathy for the plaintiff and defendant. To assess participants, feelings toward the litigants, they gave ratings on a scale from -100 to +100 in response to the questions "How much sympathy do you feel for the plaintiff (defendant)?" They were instructed that negative numbers should be used to indicate negative feelings, positive numbers to show positive feelings, and 0 to reflect indifference. These questions were included to allow an assessment of the relationship between subjects' feelings toward the litigants and 
Table 2

Effect of Injury Severity on Mean Sympathy Ratings, Studies 1 and 2

\begin{tabular}{crc}
\hline & \multicolumn{2}{c}{ Injury severity } \\
\cline { 2 - 3 } & Low & High \\
\hline Study $1(N=76)$ & & \\
Plaintiff & $26.6(50.2)$ & $68.4(33.3)^{* * *}$ \\
Defendant & $9.6(19.8)$ & $-5.7(42.0)^{*}$ \\
Study 2 $(N=156)$ & & \\
Plaintiff & $28.2(37.7)$ & $69.7(36.3)^{* * *}$ \\
Defendant & $8.8(34.6)$ & $-5.1(40.0)^{*}$ \\
\hline
\end{tabular}

Note. Participants rated their feelings for both the plaintiff and the defendant on a scale ranging from -100 to 100 . Standard deviations are in parentheses. Significance tests are for the effect of injury severity.

${ }^{*} p<.05 . * * * p .001$.

their liability judgments, and to see if sentiment toward one litigant would affect feelings for the other party. Previous research has found evidence of such a spillover effect in feelings toward the major participants at trial (Bornstein, 1994; Greene, Wilson, \& Loftus, 1989).

\section{Results and Discussion}

Seven participants were dropped from the analyses - 3 who did not understand the instructions, and 4 for having taken part in a previous pilot version of the study-leaving a total of 76 participants ( 47 males, 29 females). The variable of participant gender affected only one of the dependent measures, sympathy for the plaintiff, with females feeling more positively toward the female plaintiff, $t(74)=2.62, p=.01$. Gender did not interact with severity on any of the dependent variables. The following analyses are therefore collapsed across participant gender. Cohen's $d$ and $w$ are included as measures of effect size (Rosenthal \& Rosnow, 1991 ).

Feelings for the Litigants

Participants' sympathy ratings for both litigants are shown in Table 2. 
Plaintiff sympathy. The plaintiff whose injury had more severe consequences was perceived in a significantly more positive light, $t(74)=4.29, p<$ $001, d=1.0$. Thus, varying the severity of the plaintiffs injury proved to be an effective means of manipulating participants' feelings toward the plaintiff.

Defendant sympathy. Although the defendant's behavior and characteristics were exactly the same in both conditions, the defendant who was being sued in the high-severity condition was perceived significantly less favorably, $t(74)=$ $2.03, p<.05, d=0.47$. Increasing the amount of positive sentiment felt for one party was accompanied by increased negative feelings for that party's antagonist. This reciprocal process is substantiated further by the presence of a negative correlation between sympathy for the plaintiff and sympathy for the defendant $(r=-.24, p<.05)$. This finding suggests that jurors do not perceive the participants at trial independently; rather, there is a tradeoff, such that the more favorably one feels toward one of the opposing sides, the less favorable are one's sentiments toward the other side (Bornstein, 1994; Greene et al., 1989).6

\section{Liability Judgments}

Verdicts. Overall, $30.3 \%$ of the participants found the defendant liable. Although the factual evidence was identical in both conditions, the proportion of plaintiff verdicts differed depending on the severity of her injury. Participants were almost twice as likely to find for the plaintiff in the high-severity as in the low-severity condition ( $39.5 \%$ vs. $21.1 \%$ plaintiff verdicts, respectively), $\chi^{2}=3.06, p<.04$, one-tailed, $w=0.20$.

Causation ratings. As causation was the major fact-in-issue, it was predicted that the effect of injury severity on verdicts would be reflected in terms of how participants evaluated the defendant's behavior in the two conditions. Participants rated the likelihood that the defendant caused the plaintiffs injury as higher in the high-severity $(M=41.2$ on the 0 to 100 scale, $S D=25.8)$ than in the low-severity $(M=26.6, S D=22.8)$ condition, $t(74)=2.60, p=.01, d=$ 0.60. Participants' liability judgments thus confirm the main hypothesis - that participants will make different judgments depending upon the severity of the plaintiffs injury. As the expert scientific evidence on which participants were

${ }^{6}$ An alternative means of assessing the relationship between injury severity and feelings for the litigants is to compute the correlation between severity ( 0 for low, 1 for high) and participants' sympathy ratings. This procedure facilitates a comparison of the effects. Severity was positively correlated with sympathy for the plaintiff $(r=.45, p<.001)$ and negatively correlated with sympathy for the defendant $(r=-.23, p<.05)$. These findings corroborate the primary analyses reported in the text, while also indicating that the severity manipulation had a greater impact on participants' perceptions of the plaintiff than on their perceptions of the defendant. I am grateful to an anonymous reviewer for suggesting this comparison. 
told to base their causation judgments was identical in the two conditions, the effect of severity on these judgments suggests that participants evaluated the same evidence differently, depending on severity. Because participants made a global estimate of causation and did not evaluate the scientific evidence directly in reaching a verdict, the present findings cannot address the process by which severity influences the evaluation of evidence. Future research is called for that addresses jurors' cognitive processes in evaluating scientific evidence (cf. Smith, Penrod, Otto, \& Park, 1996).

\section{Compensation}

Injury severity and sentiments have been found to correlate positively with damage awards in both simulated (Darden, DeConinck, Babin, \& Griffin, 1991) and actual cases (e.g., Genn, 1984 ). The effect appears to be stronger for some types of cases than for others (Bovbjerg, Sloan, nor, \& Hsieh, 1991 ), and extralegal factors may come into playas well (Baron \& Ritov, 1993; Goodman, Greene, \& Loftus, 1989). As the main goal of compensation is restitution for the injury, if participants award more money to more severely injured plaintiffs - once liability has been established - then they are behaving in a normative, legally appropriate manner. Compensation awards were analyzed only for participants who first found the defendant liable. Although participants awarded considerably more money to more severely injured plaintiffs $(M \mathrm{~s}=\$ 7.78$ million vs. $\$ 275,000 ; M d n \mathrm{~s}=\$ 400,000$ vs. $\$ 300,000)$, the difference was not significant, $t(13$, separate variances $)=1.06$.

The failure to attain significance is likely due to a combination of small sample size (only 23 of 76 participants found the defendant liable and hence could award compensation) and extremely high variance in the awards (the amounts ranged from hundreds of dollars to $\$ 10$ million). The absence of an effect of severity on compensation awards also shows that the requested compensation can elicit a powerful anchoring and adjustment effect (Chapman \& Bornstein, 1996; Raitz, Greene, Goodman, \& Loftus, 1990). Requested compensation was held constant across the severity conditions so that participants would not draw from it inferences about the legitimacy of the plaintiffs factual claims; however, it might have had the inadvertent effect of anchoring participants on the requested amount to such an extent that they did not make allowance for the severity of the plaintiffs injury.

\section{Relationship of Severity and Sentiment to Causation Ratings}

To show that the effect of injury severity on causation judgments is mediated by the variation in feelings toward the litigants elicited by the differ- 
ent severity conditions, a multiple regression analysis was performed to measure the extent to which differences in sympathy ratings, rather than outcome severity alone, accounted for differences in causation judgments. As predicted, regressing participants' causation estimates onto the plaintiff's injury severity and sympathy ratings for the plaintiff and the defendant was significant (adjusted $R^{2}=.27$ ), overall $F(3,72)=10.38, p<.001$. However, significant contributions to the model were made only by sympathy for the plaintiff $(B=0.17, S E=0.06, p<.01)$ and sympathy for the defendant $(B=-0.25, \mathrm{SE}$ $=0.08, p<.01)$, and not by severity in and of itself $(p>.5)$. Thus, if variation in feelings toward both litigants is held constant, outcome severity alone plays no role in the variation in causation judgments.

This analysis suggests that the effect of injury severity on participants' evaluation of the evidence is mediated by the sentiments aroused by different levels of severity. However, because participants made their sympathy ratings after judging causation, it is possible that their sentiments were influenced by their causation judgments, rather than vice versa. Although the present analysis cannot definitively rule out this possibility, it is less likely than the mediational account, for two reasons. First, pilot data obtained in developing the present stimulus materials yielded an equally large difference in sympathy ratings due to injury severity, even when participants did not judge causation. Second, it is harder to envision the process by which severity would influence causation judgments directly, as opposed to being mediated by variations in sentiments toward the litigants.

The results of Study 1 indicate that varying the severity of the plaintiff's injury elicited different sentiments, which biased participants' evaluation of the evidence so that it favored the more severely injured plaintiff, who was consequently more likely to win her case. Injury severity affected feelings toward both the plaintiff and the defendant, and feelings toward both litigants had an extralegal influence on participants' liability judgments.

\section{Study 2}

Although Study 1 clearly demonstrates an effect of injury severity on participants' factual judgments, it does not address how the effect operates. One explanation is that severity could relate to some relevant prior belief. For example, Bornstein (1994) found that participants' tendency to treat civil defendants differently as a function of their status (i.e., a corporation vs. an individual) reflected a general belief that corporate defendants were more likely to cause harm, other factors being equal. In the case of injury severity, jurors might feel that a particular action by a defendant is simply more likely to cause a severe than a mild injury. If so, the extralegal factor of injury severi- 
ty would then be used as a piece of evidence in making the decision and could explain why it influenced liability judgments in Study 1.

Alternatively, severity could influence jurors' decisions solely by virtue of its relationship to their feelings. The analysis of Study 1 established that injury severity in and of itself did not influence participants' liability judgments; rather, its effect was mediated by the feelings aroused by different degrees of injury. Different emotional states are associated with different motives or action tendencies (Frijda, 1987; Frijda et al., 1989). Since the extent of the plaintiffs injury affected participants' feelings toward both the plaintiff and the defendant, and both of these sentiments influenced their liability judgments, there are two distinct action tendencies that could be involved. A severe injury that arouses positive sentiment for the plaintiff might be associated with a specific motivational state to help the plaintiff by alleviating her suffering (Batson et al., 1983, 1987), while the same injury's arousal of negative feelings toward the defendant could produce a motivational state to punish the allegedly responsible party. In either case, the goal can only be achieved by evaluating the evidence in a direction favoring the plaintiff and finding the defendant liable.

Study 2 was designed to investigate further the exact nature of the relationship between injury severity and judgments of liability and compensation. If greater severity leads to a specific motivation to see the severely injured party compensated or to punish the person allegedly responsible, then different levels of injury severity will affect participants' judgments only when they have the power to compensate or to punish. If, on the other hand, participants have a prior belief concerning causation and injury severity, it will be reflected in their liability judgments whenever injury severity varies.

Study 2 is a replication and extension of Study 1. In addition to the normal trial situation, where jurors are in a position to determine both liability and the amount of compensatory damages awarded to the plaintiff (Norm condition), two other decision contexts are used. In the first of these two conditions (separated trial, or Sep condition), participants determined liability and punitive damages against the defendant, but these damages were not to be paid to the plaintiff, as is customary in civil suits; furthermore, participants did not award compensatory damages to the plaintiff (modeled after Baron \& Ritov, 1993 ). Thus, participants in this condition were not in a position to award any money to the plaintiff, but they could punish the defendant. The second new condition was a Control condition in which participants' task was only to evaluate the evidence and to determine liability; they awarded no damages of any sort. For all three conditions, or decision contexts, injury severity was varied.

It is hypothesized that because injury severity affects participants' feelings toward the litigants, a more severe injury will induce a stronger motivation- 
al state; therefore, injury severity will influence participants' liability judgments only when they are in a position to act upon that motivation by awarding damages - that is, in the Norm and Sep conditions. Participants' liability judgments in the Control condition, where they are unable to award damages, will not differ as a function of severity. Although participants' task in the Norm condition emphasizes compensating the plaintiff, the compensation is nonetheless paid by the defendant. Hence, traditional compensation has the dual effects of punishing the defendant, by his incurring a financial loss, as well as providing restitution to the plaintiff (Landes \& Posner, 1987). Compensation can thereby satisfy both possible motives: to help the plaintiff and to punish the defendant. The Sep condition, on the other hand, allows only punishment of the defendant. A secondary hypothesis is thus that the effect of severity will be stronger in the Norm than in the Sep condition.

\section{Method}

\section{Participants}

Participants were 160 undergraduates who received extra course credit. Although demographic information such as race and age was not requested of participants, the larger sample from which they were drawn was predominantly White ( $\sim 90 \%)$ and between the ages of 18 and 25 (the limitations of the sample are discussed in the General Discussion section). Four participants failed to follow instructions, leaving a total of 156 participants (47 male, 108 female, and 1 participant who did not indicate gender).

\section{Materials and Design}

The same case, with a high- and low-severity condition, was used as in Study 1 . The design was a $2 \times 3$ (Injury Severity $\times$ Decision Context) between-subjects design. Twenty-six participants were randomly assigned to each condition.

\section{Procedure}

The first part of the instructions was similar to those used in Study 1. The remainder of the one-page instruction sheet differed depending on which decision context the subject was in. Instructions for the Norm condition were the same as in Study 1. In the remaining two decision contexts, participants were told (modeled after Baron \& Ritov, 1993):

Imagine . . that a few years from now, the U.S. has a new law concerning medical misfortunes, such as injuries or diseases. According to 
this law, anyone who suffers such a misfortune can request monetary damages. . . For each request, two questions will be decided separately, each by a different panel.

The first panel will decide whether the defendant will be fined, and, if so, how much. All fines go into a government fund, not to the plaintiff. The panel that decides the fines considers only the justice of imposing the fines, which depends on whether the defendant actually caused the harm.

The second panel will decide how much money the plaintiff will receive. If any monetary damages are paid, the government pays them out of the fund, not the defendant. This panel takes into account only the situation of the injured plaintiff . . The government does not have to break even in the long run. The injured person can ask for money no matter what caused the misfortune. The panels operate independently.

Participants in the Sep condition were then told to imagine that they were on the first panel, while participants in the Control condition were told to imagine that they were not on either panel. Control participants were told that their task was neither to fine the defendant nor to compensate the plaintiff, but instead to provide an objective baseline from which to evaluate the accuracy of others' judgments. Thus, participants in all three decision contexts were asked to evaluate the evidence and to determine liability by estimating how likely the defendant was to have caused the plaintiffs injury. The conditions differed in the type of monetary judgment participants were asked to make.

Participants completed questionnaires individually, with up to 10 people included in a single session. Following completion of the questionnaire, they filled out a survey which asked them about the extent to which their beliefs influenced their responses; specifically, they were asked if their feelings toward the litigants in the particular case influenced their judgments, and if they should, in general, for real jurors. These questions were included to assess whether participants were aware of the potential influence of extralegal factors on their judgments. After completing the feedback survey, participants were thanked and debriefed. The entire procedure took roughly 30 to $45 \mathrm{~min}$ to complete.

As in Study 1, participants reached a verdict, estimated the probability that the defendant caused the plaintiffs injury, awarded damages (if appropriate), and rated their feelings toward the litigants. 


\section{Results and Discussion}

As in Study 1, the only effect of participant gender was on ratings of sympathy for the plaintiff, with females feeling marginally more positive, $F(1$, $151)=3.61, p<.06$. A significant interaction between gender and severity, $F(1,151)=5.45, p<.05$, indicated that this gender difference in feelings toward the plaintiff was confined to the severely injured plaintiff. As there were no other effects of participant gender, the following results are collapsed across gender.

\section{Feelings for the Litigants}

Participants' sympathy ratings were analyzed by separate $2 \times 3$ (Injury Severity $\times$ Decision Context) ANOVAs. The severity-of-injury manipulation was again very effective at eliciting different amounts of sympathy (Table 2). Participants felt more positively toward the severely injured plaintiff; $F(1,150)=$ $48.46, p<.001, d=1.14$, and they felt more negatively toward the defendant who had allegedly caused the more severe injury, $F(1,150)=5.27, p<.025$, $d=0.38 .{ }^{7}$ There was no main effect of decision context on sympathy ratings, nor did it interact with severity.

\section{Liability Judgments}

It was hypothesized that severity would influence liability judgments in the Norm and Sep conditions, but not in the Control condition. These specific hypotheses allow for planned comparisons on the effect of severity within each decision context. In addition, it was hypothesized that the effect of severity on liability judgments would be greater in the Norm condition, where participants could compensate the plaintiff directly, than in the Sep condition, where they could punish the defendant but not compensate the plaintiff. This interaction was tested by logistic regression, for the dichotomous verdict data, and with a $2 \times 2$ ANOVA on the continuous causation ratings.

Verdicts. The proportion of liable (i.e., plaintiff) verdicts in each condition is shown in Table 3 . The effect of injury severity was significant within the Norm and Sep conditions, $\chi^{2}(d f=1, N=52)=8.31$ and 4.46, respectively; $p \mathrm{~s}<05$, ws $=0.23,0.17$, where participants awarded damages, but not with-

${ }^{7}$ As in Study 1, correlational analyses were also performed. Injury severity was positively correlated with sympathy for the plaintiff $(r=.49, p<.001)$, but negatively correlated with sympathy for the defendant $(r=-.18, p<.05)$; as in Study 1 , the relative magnitude of the correlations suggests a stronger effect of severity on feelings for the plaintiff. 


\section{Table 3}

\section{Percentage of Liable Verdicts as a Function of Injury Severity and Decision Context}

\begin{tabular}{lccc}
\hline & \multicolumn{3}{c}{ Injury severity } \\
\cline { 2 - 4 } Decision Context & Low & High & Total \\
\hline Normal trial & 7.7 & $42.3^{* *}$ & 25.0 \\
Separated trial & 7.7 & $30.8^{*}$ & 19.2 \\
Control & 19.2 & 26.9 & 23.1 \\
Total & 11.5 & 33.3 & 22.4 \\
\hline
\end{tabular}

Note. $N=26$ in each condition. Significance tests are for the effect of injury severity within each decision context.

${ }^{*} p<.05$. ${ }^{* *} p<.005$.

in the Control condition, $\chi^{2}(d f=1, N=52)<0.5$. Regressing verdicts onto injury severity and decision context, including only the Norm and Sep conditions, yielded a significant contribution of severity $(B=0.96, S E=0.30, p=$ $.001)$ but a nonsignificant interaction $(p>.5)$, indicating that the effect of severity was equally strong in the Norm and Sep conditions. These findings suggest that injury severity is associated with a strong motivational component, and that it will affect jurors' verdicts only when they can award damages. Further, the motives aroused by a severe injury can be satisfied equally well by compensating the plaintiff or punishing the defendant.

Causation. Within each decision context (Figure 1), planned contrasts showed that greater injury severity influenced participants' evaluation of the evidence in a direction favorable to the plaintiff in the Norm condition, $F(1$, $150)=9.74, p<.005, d=0.51$; marginally in the Sep condition, $F(1,150)=$ $3.01, p=.085, d=0.28$; but had no effect on participants in the Control condition, $F(1,150)=1.84, p>.17$. A two-way ANOVA with severity and decision context (Norm or Sep) as the independent variables yielded a significant effect of severity, $F(1,100)=11.34, p<.001, d=0.67$, but a nonsignificant interaction, $F<1$.

Although the differential feelings for the litigants elicited in the high-severity versus the low-severity condition were the same in all decision contexts, participants' liability judgments varied only in the Norm and Sep conditions, where they could award damages. This finding suggests that partic- 


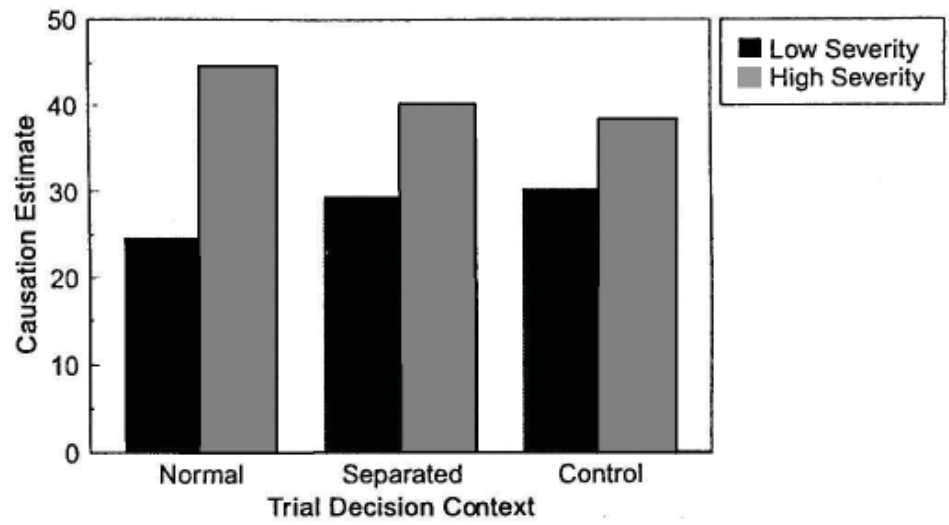

Figure 1. Causation judgments as a function of injury severity and decision context.

ipants were not relying on a prior belief about causation and injury severity but were displaying motivated behavior. Participants who could compensate the injured plaintiff or punish the defendant were more likely to be influenced by injury severity than were those who could not. Feelings aroused by a severe injury appear to operate by producing a specific motivation to alleviate the injured party's suffering or, to a somewhat lesser extent, to punish the defendant. In order to accomplish either of these goals, participants must first find the defendant liable. Because the motivations associated with feelings for the litigants are stronger when the plaintiff has been more severely injured, injury severity consequently has a greater effect in circumstances where participants have the opportunity to act by awarding damages. Contrary to expectation, even though both ends were served in the Norm condition, the effect of injury severity on participants' liability judgments was equally strong whether they were awarding compensatory or purely punitive damages.

\section{Monetary Damages}

The different conditions asked different questions regarding monetary damages: Participants in the Norm condition compensated plaintiffs directly, those in the Sep condition fined defendants but did not compensate plaintiffs, and Control participants made no judgments involving money. Analyses were therefore performed within the first two conditions to evaluate the effect of injury severity on both kinds of awards. As in Study 1, damage awards tended to be larger when the plaintiff was more severely hurt. This trend was apparent both when the plaintiff was compensated directly (Norm $M \mathrm{~s}=\$ 609,000$ vs. $\$ 375,000, M d n$ s $=\$ 300,000$ vs. $\$ 375,000)$ and when the defendant was 
fined but the plaintiff did not receive the damages herself ( $\operatorname{Sep} M \mathrm{~s}=\$ 587,500$ vs. $\$ 175,000, M d n s=\$ 500,000$ vs. $\$ 175,000)$. The difference was significant in the Sep, $t(5.9$, separate variances $)=3.14, p<.025$, but not in the Norm condition, $t(8.3$, separate variances $)=0.94$. However, as few subjects found the defendant liable in the low-severity condition-only two participants in each decision context where damages were awarded - these statistical comparisons must be interpreted cautiously. Future research is needed in which participant jurors award damages in both high- and low-severity cases where the defendant's liability has already been established. Nonetheless, these results suggest that participant jurors were influenced by the variable of injury severity both when it was relevant (i.e., in awarding compensation) and when it was not, in merely punishing the defendant.

\section{Participants'Beliefs About the Influence of Feelings on Their Judgments}

After responding to the case, participants were asked whether their feelings toward the litigants influenced their liability judgments. In addition, they were asked whether jurors in general should be influenced by their feelings toward litigants. For each question, participants responded "Yes," "No," or "Maybe/Unsure." For the following analyses, Yes and Maybe responses were combined into a single category in order to avoid having too few participants in some cells (including them as separate response categories yielded comparable results ).

Approximately one quarter of participants $(26.3 \%)$ said that their liability judgments were or might have been influenced by how they felt, while $22.7 \%$ of participants believed that, in general, jurors' causation judgments should definitely or perhaps be influenced by their feelings toward the litigants. Participants were more likely to report an influence of sentiment on their own judgments if they believed that it should influence actual jurors, $\chi^{2}(d f=1, N=$ 156) $=25.83 ; p<.001, w=0.41$.

Participants' self-reports were reliable predictors of their liability judgments. Participants were more likely to find the defendant liable when they responded that they had (or might have been) influenced by their feelings (46.3\% liable verdicts) than when they had not been (13.9\% liable verdict), $\chi^{2}(d f=1, N=156)=18.26, p<.001, w=0.34$, and also when they believed jurors in general ought to consider sentiment in reaching a verdict $(37.1 \% \mathrm{vs}$. $18.5 \%$ liable verdicts), $\chi^{2}(d f=1, N=156)=5.36, p<.025, w=0.19$. A similar pattern of results was obtained using participants' causation judgments as the dependent variable: Participants who reported being influenced by their feelings or who believed that jurors in general should consider their feelings rated the defendant as more likely to have caused the plaintiffs injury than 
those who did not, $F(1,152)=14.07, p<.001, \mathrm{~d}=0.61$, and $F(1,150)=9.41$, $p<.005, d=0.50$, respectively.

Overall, participants' self-reported beliefs contradicted their actual behavior. Although $73.7 \%$ of participants claimed that extralegal sentiment did not influence their judgments, and $77.3 \%$ said that it should not, the results indicate that feelings toward the litigants had a powerful effect on participants' evaluation of the evidence. Participants' self-reports were reliable indexes of their behavior, such that those who reported being influenced by their feelings actually were; that is, they were more likely to favor the plaintiff than were participants who denied being influenced by their feelings.

In summary, the results of Study 2 indicate that the effect of injury severity on participants' factual judgments is mediated by the opportunity to award compensation or to punish the defendant. Relatively severe injuries elicit a desire to compensate the plaintiff, to punish the defendant, or both; when these desires can be satisfied by a certain interpretation of the evidence, injury severity consequently influences participants' liability judgments that are based on their evaluation of the evidence. This pattern is particularly true for participants who are aware that their feelings are affecting their judgments. Since an effect of injury severity on liability judgments not only violates legal guidelines but also occurs in the absence of a relevant expectation, it constitutes a decision-making bias. The effect of severity is equally strong whether participants' damage awards are paid to the plaintiff or not, but removing their capacity to award any damages reduces the bias.

\section{General Discussion}

Participants did not use the evidence presented at trial strictly as intended by the law. Effect size indexes in Study 1 showed a medium-sized effect of the severity of the plaintiffs injury on participants' liability judgments (Rosenthal \& Rosnow, 1991 ), indicating a fairly substantial influence of this extralegal factor. However, a severe injury was not sufficient, in and of itself, to sway participants' judgments. A relatively severely injured plaintiff was viewed more favorably than a less severely injured plaintiff. A more severe injury also caused the defendant to be perceived correspondingly less favorably, even though the defendant's behavior was identical, regardless of the injury's consequences. Study 1 established that the influence of injury severity was mediated by its effect on participants' feelings toward both litigants. This result supports previous research showing that feelings for the various participants at trial influence one another (Bornstein, 1994; Greene et al., 1989), and that these sentiments can influence jurors' interpretation of the evidence (Bornstein, 1994; Kalven \& Zeisel, 1966). 
Study 2 extended this finding by showing that variations in the severity of the plaintiff's injury affected liability judgments only when participants could award damages. One explanation of this finding is that the sentiments aroused by a severe injury induce a particular action tendency (Frijda, 1987; Frijda et al., 1989), in this case to help the plaintiff by awarding compensation, or to punish the defendant by awarding a fine. Although compensatory damages take money from the defendant as well as provide restitution to the plaintiff, injury severity does not appear to motivate behavior more strongly in this circumstance than when punitive damages are awarded without the money going to the plaintiff. If neither action tendency can be satisfied, as in the control condition where participants did not award any damages, then severity does not affect liability judgments. Thus, the effect of severity on liability judgments supports findings from the motivation and emotion literature that a major component of emotional experience is the tendency to act in a certain way (e.g., Frijda et al., 1989). Emotions aroused within the context of a trial can have the same general effects as emotions aroused in other situations.

Various approaches to the study of juror decision making have in common a view of jurors' task as involving the weighing of different kinds of information in assessing the relative likelihood of competing hypotheses (e.g., Hastie, 1993; Kaye, 1988). As a number of cognitive biases tend to occur in complex decision-making situations generally (e.g., Tversky \& Kahneman, 1974), they can be expected to affect jurors' reasoning as well (Arkes, 1989; Saks \& Kidd, 1980). For example, jurors demonstrate hindsight bias when the outcome of some behavior influences their evaluation of evidence on which the behavior, such as a possibly illegal police search, was based (Casper \& Benedict, 1993 ).

Juror hindsight bias differs slightly from the effect of injury severity demonstrated in the present studies in that hindsight subjects are influenced by knowledge of whether or not an event has occurred (or which of alternative events has occurred), while in personal-injury cases, a single, specific event has occurred (i.e., the injury) which can vary in its consequences. For practical purposes, however, this distinction makes little difference; in both instances, jurors' judgments about facts-in-issue are influenced by outcome information that is legally irrelevant, though it might be relevant to other judgments, such as the awarding of damages.

Because of the similarity between hindsight bias and the effect of injury severity, proposed techniques for reducing their effects are similar as well (Wexler \& Schopp, 1989). For example, judges' instructions could emphasize that jurors should not be influenced by their feelings toward the litigants. This proposal would require little change from current procedure, as jurors are usually already told to consider only the formally presented evidence and to exclude any prior prejudices (Devitt et al., 1992). In combating the influence of 
jurors' sentiments, judges could make this point even more strongly, and perhaps even single out specific factors likely to arouse sentiment, such as the presence of a severe injury. However, because merely warning people about a possible bias has failed at eliminating the effects of other cognitive biases, such as hindsight (Casper \& Benedict, 1993; Fischhoff, 1982), this technique is unlikely to be successful.

A more radical proposal for eliminating the effect of extralegal factors on jurors' factual judgments, which would involve a greater departure from normal judicial procedure, would be to separate civil trials into two distinct, independent phases: a fact-finding phase and a damages phase, involving separate decision-making bodies whose decisions are not contingent on one another. Separating claims or issues at trial is permitted by Rule 42(b) of the Federal Rules of Civil Procedure and has been proposed as one means of improving the quality of juror decision making, especially in complex cases (Cecil, Hans, \& Wiggins, 1991; Hammitt, Carroll, \& Relies, 1985). This approach is suggested by the results of Study 2, in which severity influenced participants' evaluations of the evidence only when they were in a position to award damages. Bifurcated trials would thus produce fairer decisions by eliminating the influence of this extralegal variable, and possibly others as well. Furthermore, bifurcation would not necessarily work to the disadvantage of one party or the other. Horowitz and Bordens (1990) found that in a simulated toxic tort trial, separation of the issues resulted in fewer verdicts for the plaintiff, but larger damage awards if the defendant was first found liable.

The effect of injury severity differs from hindsight bias in that the emotional response produced by variations in severity is the critical determinant of its effect on liability judgments. Thus, a prescriptive approach specific to the factor of severity could address the issue of jurors' feelings. One technique for dealing with jurors' sentiments is to attempt to "desensitize" potential jurors by having the injured plaintiff appear during jury selection (Green, 1990). In Study 2, participants who reported having been influenced by how they felt toward the litigants were more likely to find the defendant liable. This result suggests that presenting the plaintiff's injuries during voir dire, and asking jurors if they felt that those injuries would unduly influence their appraisal of the factual evidence, would be an effective means of reducing the injuries' potentially biasing effect. Such a procedure has very little cost, as plaintiffs frequently appear at the voir dire anyway. It is important to note that removing such jurors would not be prejudicial to the plaintiff; injury severity could, and presumably still would, be used in determining compensation, for which it is legally relevant.

In recommending corrective procedures based on generalizing from the present results to the behavior of real jurors, it is important to highlight the major differences between the present methodology and actual trials. The 
participants in the present studies were not actual jurors, and they read a brief summary of a trial, rather than being presented with a cognitively much more demanding live trial. Furthermore, an undergraduate student sample is not representative of a community-wide jury pool; it is unusually homogeneous in terms of race, age, and socioeconomic status. It is difficult to know the extent to which the results of such simulations can be applied to courtroom situations (Bray \& Kerr, 1982). For example, student jurors might differ from a more representative sample of jury-eligible adults in coming disproportionately from relatively high-income groups or in their view of what constitutes a lot or a little money in terms of damages. Although the behavior of student mock jurors has not been shown to differ systematically from that of nonstudents, variables that covary with student status - such as race, income, and education level—can affect mock jurors' use of extralegal information (Bornstein \& Rajki, 1994). Thus, it is not known if injury severity would influence jurors drawn from a more diverse population in the same way as participants in the present studies; its effects could be greater, less, or the same.

Although the manipulation of injury severity might have stood out more in the brief experimental descriptions than it would have in a richer, more complex trial, little research has been conducted on the effect of using simulations with varying degrees of verisimilitude, and that which has been done offers conflicting results (e.g., Bermant, McGuire, McKinley, \& Salo, 1974; Juhnke et al., 1979). Importantly, even if a simulation's verisimilitude did have a consistent main effect (e.g., a greater proportion of plaintiff verdicts in more realistic trials), it does not necessarily follow that this variable would interact with other variables of interest (cf. Kramer \& Kerr, 1989) - that is, there is no reason to predict that the effect of injury severity would be either greater or less with a videotaped simulation, as opposed to a written summary.

Thus, despite these limitations, and taken with a proper degree of caution, the present results have potential applications to legal practice. Of course, any modification of existing judicial procedures has costs as well as benefits (Saks, 1989). For example, trying issues before two entirely different juries has the disadvantage of requiring more expense, time, and jurors (for a more detailed discussion of the tradeoffs involved in bifurcation, see Wexler $\&$ Schopp, 1989). Depending on the outcome of future studies exploring the efficacy of less disruptive attempts to eradicate the effect of cognitive biases on juror decision making, such as judges' instructions and voir dire, bifurcation merits serious consideration. The benefits to the jury system of reducing the influence of extralegal factors, such as the severity of a plaintiffs injury, must be weighed against the increased costs in time, money, and encumbering the trial process. 


\section{References}

Arkes, H. R. (1989). Principles in judgment/decision making research pertinent to legal proceedings. Behavioral Sciences and the Law, 7, 429-456.

Baron, J., \& Ritov, I. (1993). Intuitions about penalties and compensation in the context of tort law. Journal of Risk and Uncertainty, 7, 17-33.

Batson, D. D., Fultz, J., \& Schoenrade, P. A. (1987). Adults' emotional reactions to the distress of others. In N. Eisenberg \& J. Strayer (Eds. ), Empathy and its development (pp. 163-184). Cambridge, UK: Cambridge University Press.

Batson,C. D., O'Quin, K., Fultz, J., Vanderplas, M., \& Isen, A. M. (1983). Influence of self-reported distress and empathy on egoistic versus altruistic motivation to help. Journal of Personality and Social Psychology, 45, 706-718.

Bermant, G., McGuire, M., McKinley, W., \& Salo, C. (1974). The logic of simulation in jury research. Criminal Justice and Behavior, 1, 224-233.

Bornstein, B. H. (1994). David, Goliath, and Reverend Bayes: Prior beliefs about defendants' status in personal injury cases. Applied Cognitive Psychology, 8, 233258.

Bornstein, B. H., \& Rajki, M. (1994). Extra-legal factors and product liability: The influence of mock jurors' demographic characteristics and intuitions about the cause of an injury. Behavioral Sciences and the Law, 12, 127-147.

Bovbjerg, R. R., Sloan, F. A., Dor, A., \& Hsieh, C. R. (1991 ). Juries and justice: Are malpractice and other personal injuries created equal? Law and Contemporary Problems, 54, 5-41.

Bray, R. M., \& Kerr, N. L. (1982). Methodological considerations in the study of the psychology of the courtroom. In N. L. Kerr \& R. M. Bray (Eds.), The psychology of the courtroom (pp. 287-323). New York, NY: Academic.

Burger, J. M. (1981 ). Motivational biases in the attribution of responsibility for an accident: A meta-analysis of the defensive-attribution hypothesis. Psychological Bulletin, 90, 496-512.

Calfee, J. E., \& Winston, C. (1988). Economic aspects of liability rules and liability insurance. In R. E. Litan \& C. Winston (Eds.), Liability: Perspective and policy (pp. 16-41). Washington, DC: Brookings.

Casper, J. D., \& Benedict, K. M. (1993). The influence of outcome information and attitudes on juror decision making in search and seizure cases. In R. Hastie (Ed.), Inside the juror (pp. 65-83 ). Cambridge, UK: Cambridge University Press.

Cather, C., Greene, E., \& Durham, R. (1996). Plaintiff injury and defendant reprehensibility: Implications for compensatory and punitive damage awards. Law and Human Behavior, 20, 189-205. 
Cecil, J. S., Hans, V. P., \& Wiggins, E. C. (1991). Citizen comprehension of difficult issues: Lessons from civil jury trials. American University Law Review, 40, 727774.

Chapman, G. B., \& Bornstein, B. H. (1996). The more you ask for, the more you get: Anchoring in personal injury verdicts. Applied Cognitive psychology, 10, 519-540.

Chin, A., \& Peterson, M. (1985). Deep pockets, empty pockets. who wins in Cook County jury trials. Santa Monica, CA: The RAND Corporation.

Clore, G. L. (1994). Why emotions vary in intensity. In P. Ekman \& R. J. Davidson (Eds.), The nature of emotion (pp. 386-393). New York, NY: Oxford University Press.

Cruse, D., \& Leigh, B. C. (1987). “Adam's Rib” revisited: Legal and non-legal influences on the processing of trial testimony. Social Behaviour, 2, 221-230.

Dane, F. C., \& Wrightsman, L. S. (1982). Effects of defendants' and victims' characteristics on jurors' verdicts. In N. L. Kerr \& R. M. Bray (Eds. ), The psychology of the courtroom (pp. 83-115). New York, NY: Academic.

Darden, W. R., DeConinck, J. B., Babin, B. J., \& Griffin, M. (1991). The role of consumer sympathy in product liability suits: An experimental investigation of loose coupling. Journal of Business Research, 22, 65-89.

Davis, J. H. (1989). Psychology and law: The last fifteen years. Journal of Applied Social Psychology, 19, 199-230.

Devitt, E. J., Blackmar, C. B., Wolff, M. A., \& O’Malley, K. F. (1992). Federal jury practice and instructions: Civil and criminal (4th ed., Vol. 1). St. Paul, MN: West.

Fincham, F. D., \& Jaspars, J. (1980). Attribution of responsibility: From man the scientist to man as lawyer. In L. Berkowitz (Ed.), Advances in experimental social psychology (Vol. 14, pp. 81-138). New York, NY: Academic.

Fischhoff, B. (1982). Debiasing. In D. Kahneman, P. Slovic, \& A. Tversky (Eds.), Judgment under uncertainty: Heuristics and biases (pp. 422-444 ). Cambridge, UK: Cambridge University Press.

Frijda, N. H. (1987). Emotion, cognitive structure, and action tendency. Cognition and Emotion, 1, 115-143.

Frijda, N. H., Kuipers, P., \& ter Schure, E. (1989). Relations among emotion, appraisal, and emotional action readiness. Journal of Personality and Social Psychology, 57, 212-228.

Genn, H. (1984). Who claims compensation: Factors associated with claiming and obtaining damages. In D. Harris, M. Maclean, H. Genn, S. Lloyd-Bostock, P. Fenn, P. Corfield, \& Y. Brittan (Eds. ), Compensation and support for illness and injury (pp. 46-79). Oxford, UK: Clarendon.

Goodman, J., Greene, E., \& Loftus, E. F. (1989). Runaway verdicts or reasoned deter- 
minations: Mock juror strategies in awarding damages. Jurimetrics Journal, 29, 285-309.

Green, W. E. (1990, April 18). Attorneys try to defuse sympathy in injury cases. The Wall Street Journal, p. B1.

Greene, E., Wilson, L., \& Loftus, E. F. (1989). Impact of hypnotic testimony on the jury. Law and Human Behavior, 13, 61-78.

Hammitt, J. K., Carroll, S. J., \& Relies, D. S. (1985). Tort standards and jury decisions. Journal of Legal Studies, 14, 751-762.

Hans, V. P., \& Ermann, M. D. (1989). Responses to corporate versus individual wrongdoing. Law and Human Behavior, 13, 151-166.

Hart, H. L. A., \& Honore, T. (1985). Causation in the law (2nd ed.). Oxford, UK: Clarendon.

Hastie, R. (1993). Introduction. In R. Hastie (Ed.), Inside the juror (pp. 3-41). Cambridge, UK: Cambridge University Press.

Horowitz, I. A., \& Bordens, K. S. (1988). The effects of outlier presence, plaintiff population size and aggregation of plaintiffs on simulated civil jury decisions. Law and Human Behavior, 12, 209-229.

Horowitz, I. A., \& Bordens, K. S. (1990). An experimental investigation of procedural issues in complex tort trials. Law and Human Behavior, 14, 269-285.

Huber, P. W. (1988). Liability: The legal revolution and its consequences. New York, NY: Basic Books.

Juhnke, R., Vought, C., Pyszczynski, T., Dane, F., Losure, B., \& Wrightsman, L. (1979). Effects of presentation mode upon mock jurors' reactions to a trial. Personality and Social Psychology Bulletin, 5, 36-39.

Kalven, H., \& Zeisel, H. (1966). The American jury. Boston, MA: Little, Brown.

Kaye, D. H. (1988). What is Bayesianism? In P. Tillers \& E. D. Green (Eds.), Probability and inference in the law of evidence (pp. 1-19). Dordrecht, The Netherlands: Kluwer.

Kramer, G. P., \& Kerr, N. L. (1989). Laboratory simulation and bias in the study of juror behavior: A methodological note. Law and Human Behavior, 13, 89-99.

Landes, W. M., \& Posner, R. A. (1987). The economic structure of tort law. Cambridge, MA: Harvard University Press.

Leeper, R. W. (1963 ). The motivational theory of emotion. In C. L. Stacey \& M. F. DeMartino (Eds.), In understanding human motivation (rev. ed., pp. 657-665). Cleveland, OH: Howard Allen.

Phares, E. J., \& Wilson, K. G. (1972). Responsibility attribution: The role of outcome severity, situational ambiguity, and internal-external control. Journal of Personality, 40, 392-406. 
Raitz, A., Greene, E., Goodman, J., \& Loftus, E. F. (1990). Determining damages: The influence of expert testimony on jurors' decision making. Law and Human Behavior, 14, 385-395.

Reskin, B. F., \& Visher, C. A. (1986). The impacts of evidence and extralegal factors in jurors' decisions. Law and Society Review, 20, 423-438.

Rosenthal, R., \& Rosnow, R. L. (1991). Essentials of behavioral research (2nd ed.). New York, NY: McGraw-Hill.

Saks, M. J. (1989). Legal policy analysis and evaluation. American Psychologist, 44, $1110-1117$.

Saks, M. J., \& Kidd, R. F. (1980). Human information processing and adjudication: Trial by heuristics. Law and Society Review, 15, 123-160.

Sigall, H., \& Ostrove, N. (1975). Beautiful but dangerous: Effects of offender attractiveness and nature of the crime on juridic judgment. Journal of Personality and Social Psychology, 31, 410-414.

Smith, B. C., Penrod, S. D., Otto, A. L., \& Park, R. C. (1996). Jurors' use of probabilistic evidence. Law and Human Behavior, 20, 49-82.

Tversky, A., \& Kahneman, D. (1974). Decision making under uncertainty: Heuristics and biases. Science, 185, 1124-1131.

Vidmar, N. (1993). Empirical evidence on the deep pockets hypothesis: Jury awards for pain and suffering in medical malpractice cases. Duke Law Journal, 43, $217-$ 266.

Walster, E. (1966). Assignment of responsibility for an accident. Journal of Personality and Social Psychology, 3, 73-79.

Weiner, B., \& Graham, S. (1989). Understanding the motivational role of affect: Lifespan research from an attributional perspective. Cognition and Emotion, 3, 401419.

Wexler, D. B., \& Schopp, R. F. (1989). How and when to correct for juror hindsight bias in mental health malpractice litigation: Some preliminary observations. $B e-$ havioral Sciences \& the Law, 7, 485-504. 